\title{
Modern Demographic Processes in Ukraine, Factors of Influence
}

\author{
Victoria Yavorska $^{1 *}$, Vitaliy $\mathrm{Sych}^{1}$, Ihor $\mathrm{Hevko}^{2}$, Inna Shorobura $^{3}$, and Olexandra Dolynska ${ }^{3}$ \\ ${ }^{1}$ Odesa I.I. Mechnykov National University, Champaign lane, 2, Odesa, 65058, Ukraine \\ ${ }^{2}$ Ternopil Volodymyr Hnatiuk National Pedagogical University, M. Kryvoniis st., 2, Ternopil, 46027, Ukraine \\ ${ }^{3}$ Khmelnytsky Humanities and Pedagogic Academy, Proskurivs'koho Pidpillya St, 139, Khmelnytskyi, 29013, Ukraine
}

\begin{abstract}
The presented article gives the analysis of the modern demographic indicators such as life expectancy, age structure and fertility rate of the population in Ukraine and their geographical differences. The aim of the research is a spatial analysis of the demographic situation to determine the development trends of the population of the regions of Ukraine. In the conditions of depopulation and gradual aging of labor force in Ukraine requirements to its qualitative characteristics, first of all a state of health and average life expectancy grow. Ukraine belongs to the countries with high intensity of depopulation processes that is caused by a number of various factors of economic, socio-cultural, institutional character. Large-scale and protracted depopulation is now a component and one of the most pronounced manifestations of the general crisis demographic situation in Ukraine. The tendencies of influence of average life expectancy on indicators of population aging are investigated in the work. The regional analysis is carried out and territorial differences in indicators of average life expectancy and indicators of population aging are defined. The reasons for such a tense situation have been identified. The paper emphasizes that the development of really effective measures aimed at bringing the oblasts out of the deep demographic crisis and slowing down the progressive depopulation should focus not only on reducing mortality, but mainly on improving the health of the population, which can correct high mortality. These demographic trends increase global demographic asymmetry, give a special sharpness and new "sound" to the demographic problem in the global context, and, in addition, have long-term socio-economic consequences for countries with depopulation and deepening aging. In view of this, there is now a need for a comprehensive scientific understanding of the phenomenon of depopulation and assessment of its possible prospects, the development of a strategy to influence depopulation processes by means of sociodemographic policy. In our country, the study of depopulation factors, its nature and origins, analysis of the peculiarities of the deployment of depopulation and assessment of its consequences have become particularly relevant.
\end{abstract}

\section{Introduction}

At the turn of the XX-XXI centuries in the sociogeographical development of mankind there were profound transformations that affected all aspects of his life. An important factor in new approaches to population problems has been the powerful demographic crisis in Ukraine, which has started a general depopulation since 1991.

The aim of the research is a spatial analysis of the demographic situation to determine the development trends of the population of the regions of Ukraine. The strengthening of regional differentiation and the need for scientific substantiation of the policy of "response" to the negative consequences of the gender - age structure of the population require the separation of this problem as an independent and as a specific object of study of social geography. Geographical understanding of this process involves the identification of spatio-temporal features of the gender - age structure of the population, awareness of this process for different socio-territorial systems; elucidation of factors that cause territorial differences; substantiation of measures aimed at improving the living standards of people and reducing the negative consequences of gender and age structure for various socio-territorial entities, etc.

\section{Analysis of previous researches and publications}

During last decades it has been discussed numerous issues concerning demographic situation in Ukraine which is characterized as an open demographic crisis. A fundamental contribution to the study of the given issues were done by Ukrainian scientists such as V.O. Dzhaman, O.G. Topchiev, V.A. Popovkin, V. K. Simonenko, M.S. Dnistriynskiy, K.V. Mezentcev, Z.S. Varnaliy, M.I. Dolishniy, V. Malinovskiy, M.P. Demchenko and many other domestic scientists

\footnotetext{
* Corresponding author: yavorskaya@onu.edu.ua
} 
who analyzed in detail the features of modern geodemographic development of Ukraine as a whole and its individual oblasts, substantiate possible options for further transformation of demo-reproducing processes.

\section{Research methodology}

The age structure of the population is one of the important geodemographic indicators, which characterizes the geodemographic situation and its territorial differentiation [1]. In the practice of demographic research, the analysis of age structures of the population by enlarged age groups is widespread. In this case, depending on the ratio of these three groups in the total population, there are three types of age structure. Progressive - characterized by a large proportion of children in the total population. This type of age structure is usually characterized by high rates of natural population growth. Stationary - is characterized by an almost balanced proportion of children and the elderly. This type of age structure is characterized by a small natural increase in population, or it is at a constant (stationary) level. Regressive - characterized by a fairly large proportion of the elderly. This type of age structure of the population corresponds to a narrow reproduction of the population, and sometimes it is characterized by depopulation, which takes place in Ukraine and its oblasts today $[2,3]$.

\section{Results and discussion}

According to this methodology, Volynska, Zakarpatska, Ivano-Frankivska, Lvivska, Odeska, Rivnenska, Khersonska and Chernivetska oblasts belong to the progressive type of age structure where the share of younger age groups exceeds the share of the elderly (2019) (Table 1). The Ternopilska oblast belongs to the stationary type, where the share of persons of retirement and working age is the same and the rest of the oblasts of Ukraine are referred to the regressive type of age structure of the population.

The difference between the oblasts in terms of the share of the population in real working age (15-65 years) is insignificant. Its average level in the country is $70.5 \%$, and indicators in the oblasts range from $72.6 \%$ (Kharkivska oblast) to $67.8 \%$ (Volynska oblast). The part of the working population in Kharkivska, Zaporizka, Mykolaivska, Odeska, Sumska, Khersonska, Dnipropetrovska oblasti are above the average.

The oblasts differ more in the share of the population in the older age groups (over 65 years), which has an amplitude from $19.0 \%$ (Chernihivska oblast) to $11 \%$ (Zakarpatska oblast). The average rate of this group for Ukraine is $15.3 \%$. Below the "norm" this indicator is in Zakarpatska, Rivnenska, Volynska, Chernivetska, IvanoFrankivska, Odeska, Lvivska, Khersonska, Mykolaivska, Crimea, Kharkivska oblasts. This group of oblasts has a correspondingly lower demographic burden.

The under working age group (0-14 years) has an average level in the country of $14.2 \%$ and ranges from $11.9 \%$ (Luhanska oblast) to $19.3 \%$ (Rivnenska oblast).
The highest shares $(19.3 \%-16.6 \%)$ of the under working age group are in Rivnenska, Zakarpatska, Volynska, Ivano-Frankivska and Chernivetska oblasts (Table 1).

Table 1. Indicators of the ratio of age groups of the oblasts of Ukraine (2019) *

\begin{tabular}{|c|c|c|c|}
\hline \multirow[t]{2}{*}{ Oblast** } & \multicolumn{3}{|c|}{ Population by age ( \%o) } \\
\hline & $\begin{array}{c}0-14 \\
\text { years }\end{array}$ & $\begin{array}{l}15-65 \\
\text { years }\end{array}$ & $\begin{array}{l}65 \text { years } \\
\text { and older }\end{array}$ \\
\hline Ukraine & 14.2 & 70.5 & 15.3 \\
\hline $\begin{array}{l}\text { Avtonomna } \\
\text { Respublika } \quad \text { (AR) } \\
\text { Krym }\end{array}$ & - & - & - \\
\hline Vinnytska & 14.9 & 67.8 & 17.3 \\
\hline Volynska & 18.7 & 68.2 & 13.1 \\
\hline Dnipropetrovska & 13.6 & 70.7 & 15.7 \\
\hline Donetska & - & - & - \\
\hline Zhytomyrska & 15.6 & 68.1 & 16.3 \\
\hline Zakarpatska & 18.8 & 70.2 & 11.0 \\
\hline Zaporizka & 13.1 & 71.1 & 15.8 \\
\hline Ivano-Frankivska & 16.7 & 69.3 & 14.0 \\
\hline Kyivska & 14.5 & 70.0 & 15.5 \\
\hline Kirovohradska & 14.1 & 68.9 & 17.0 \\
\hline Luhanska & - & - & - \\
\hline Lvivska & 15.6 & 70.1 & 14.3 \\
\hline Mykolaivska & 14.4 & 71.1 & 14.5 \\
\hline Odeska & 14.9 & 70.9 & 14.2 \\
\hline Poltavska & 13.1 & 69.9 & 17.0 \\
\hline Rivnenska & 19.3 & 68.3 & 12.4 \\
\hline Sumska & 12.6 & 70.8 & 16.6 \\
\hline Ternopilska & 15.7 & 68.6 & 15.7 \\
\hline Kharkivska & 12.3 & 72.6 & 15.1 \\
\hline Khersonska & 14.8 & 70.8 & 14.4 \\
\hline Khmelnytska & 14.9 & 68.5 & 16.6 \\
\hline Cherkaska & 13.4 & 69.1 & 17.5 \\
\hline Chernivetska & 16.6 & 69.5 & 13.9 \\
\hline Chernihivska & 12.7 & 68.3 & 19.0 \\
\hline
\end{tabular}

* Compiled according to the State Statistics Service of Ukraine [4]

** The names of the units of administrative division of Ukraine are represented in writing according to the [11]

On the one hand, it is a sign of increased demographic load, and on the other - better provision of their own labor resources. Further distribution of oblasts by population to under working age is as follows. The average level of this indicator $(15.7 \%-14.1 \%)$ is in Ternopilska, Zhytomyrska, Lvivska, Odeska, Vinnytska, Khmelnytska, Khersonska, Kyivska, Mykolaivska, AR Krym, Kirovohradska oblasts. The smallest share (13.6\% $-11.9 \%)$ of the under working age population is observed in Dnipropetrovska, Cherkaska, Zaporizska, Poltavska, Sumska, Kharkivska, Donetska and Luhanska oblasts. In the current demographic crisis, these oblasts will experience a certain shortage of their own labor resources.

For every 1,000 people aged 15-64 in 2019, there were 419 people, including 202 people aged $0-14$ and 217 people over 65 (Table 2 ). 
Table 2. Demographic load on the population of Ukraine aged 15-64, 2019 (per 1,000 people) *

\begin{tabular}{|c|c|c|c|c|c|c|}
\hline \multirow[t]{2}{*}{ Oblasts** } & \multicolumn{3}{|c|}{$\begin{array}{c}\text { Urban } \\
\text { settlements }\end{array}$} & \multicolumn{3}{|c|}{ Rural settlements } \\
\hline & 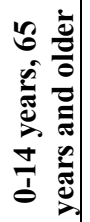 & $\begin{array}{l}\stackrel{a}{\vec{J}} \\
\underset{d}{d} \\
\frac{d}{d}\end{array}$ & 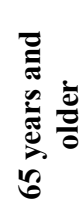 & 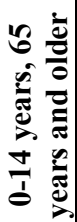 & $\begin{array}{l}\stackrel{0}{\tilde{J}} \\
\frac{\partial}{d} \\
\frac{d}{d}\end{array}$ & 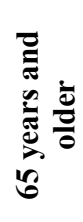 \\
\hline Ukraine & 376 & 185 & 191 & 522 & 243 & 279 \\
\hline AR Krym & - & - & - & - & - & - \\
\hline Vinnytska & 367 & 202 & 165 & 596 & 238 & 358 \\
\hline Volynska & 381 & 236 & 145 & 568 & 319 & 249 \\
\hline $\begin{array}{l}\text { Dnipro- } \\
\text { petrovska }\end{array}$ & 397 & 186 & 211 & 514 & 229 & 285 \\
\hline Donetska & - & - & - & - & - & - \\
\hline Zhytomyrska & 389 & 211 & 178 & 594 & 258 & 336 \\
\hline Zakarpatska & 396 & 253 & 143 & 441 & 276 & 165 \\
\hline Zaporizka & 382 & 174 & 208 & 492 & 221 & 271 \\
\hline $\begin{array}{l}\text { Ivano- } \\
\text { Frankivska }\end{array}$ & 372 & 216 & 156 & 503 & 263 & 240 \\
\hline Kyivska & 358 & 199 & 159 & 556 & 221 & 335 \\
\hline Kirovohrad-ska & 397 & 188 & 209 & 548 & 234 & 314 \\
\hline Luhanska & - & - & - & - & - & - \\
\hline Lvivska & 379 & 204 & 175 & 508 & 254 & 254 \\
\hline Mykolaivska & 375 & 183 & 192 & 477 & 246 & 231 \\
\hline Odeska & 378 & 183 & 195 & 478 & 268 & 210 \\
\hline Poltavska & 376 & 178 & 198 & 525 & 203 & 322 \\
\hline Rivnenska & 353 & 224 & 129 & 580 & 344 & 236 \\
\hline Sumska & 354 & 171 & 183 & 545 & 193 & 352 \\
\hline Ternopilska & 356 & 209 & 147 & 546 & 246 & 300 \\
\hline Kharkivska & 351 & 161 & 190 & 487 & 201 & 286 \\
\hline Khersonska & 394 & 192 & 202 & 444 & 237 & 207 \\
\hline Khmelnytska & 350 & 203 & 147 & 618 & 239 & 379 \\
\hline Cherkaska & 367 & 180 & 187 & 565 & 214 & 351 \\
\hline Chernivetska & 351 & 198 & 153 & 509 & 272 & 237 \\
\hline Chernihivska & 358 & 177 & 181 & 681 & 205 & 476 \\
\hline
\end{tabular}

* Compiled by the author according to the State Statistics Service of Ukraine [4]

** The names of the units of administrative division of Ukraine are represented in writing according to the [11]

In urban settlements, the load on the working population was 376 people, and in rural areas - 522 people. And in the villages there are more dependant people than working age people (demographic load is 1.5 times higher than in cities).

This situation in our country leads to such a phenomenon as "maintenance", when unemployed people are dependents of workforce. Along with this, the aging process of people should not be considered as a purely negative phenomenon. It is necessary to effectively use the experience of the elderly, to create conditions for their full life and activities.

Demographic load is calculated as the ratio of the under-working age population (up to 15 years) and postworking age (after 64 years) to the real working age population (15-64 years) per 1,000 people. In general, for Ukraine this indicator is 419 people and has amplitude of fluctuations in the oblasts from 475 people (Vinnytska oblast) to 376 people (Kharkivska oblast). It is significant that for rural settlements the demographic load is almost 1.4 times higher than in urban areas (Table 2).

According to the level of demographic load, the oblasts are distributed as follows (2019). Kharkivska, Zaporizska, Mykolaivska, and Odeska oblasts have the minimum demographic load (410 people). The second group with a moderate demographic load (410-420 people) is formed by Sumska, Khersonska, Dnipropetrovska, Odeska oblasts. A close to average level of demographic load (420-440 people) is observed in Zakarpatska, Lvivska, Kyivska, Poltavska and Chernivetska oblasts. Ivano-Frankivska, Cherkaska, Kirovohradska and Ternopilska oblasts belong to the group of oblast with a high demographic load (440-460 people). Rivnenska, Chernihivska, Volynska, Zhytomyrska, Khmelnytsks and Vinnytska oblasts have the highest demographic load (over 460 people).

The issue of "loading" the working population with the dependent population is important for many aspects of life [5]. The pension fund is formed by social taxes. In addition to children and the elderly, this social group of "dependents" also includes people with special needs. The development of effective measures to bring the oblasts out of the deep demographic crisis and slow the progressive depopulation should focus not only on reducing mortality, but mainly on improving the health of the population, which can correct the high mortality rate [6].

Retirement age is one of the key issues in the discussion of any pension system. It serves as a kind of indicator of the degree of financial stability of the pension system of social justice in society. Therefore, it is not surprising that in the course of pension reform in Ukraine, many discussions arise around the issue of rising the retirement age. Experts have very different views on this issue. If alone express the opinion of a gradual increase in the retirement age, while others categorically deny the expediency of such transformations [7].

The higher level of population aging in rural areas causes a greater demographic load than in urban settlements. At the same time, if in urban settlements the general demographic load increases annually, then in rural areas there is a decrease in the load. As the population in urban settlements is more than twice the population in rural areas, the tendency to increase the demographic load in the country as a whole is determined by the growth of this indicator in the urban population.

The next indicator of the characteristics of the population in Ukraine is the indicator of life expectancy at birth, which means the number of years that a given generation should live on average, assuming that throughout the life of the generation, when it passes from one age to another, mortality will be equal to the current mortality rate in certain age groups [8].

Average life expectancy is called expected because it is a prognostic indicator that shows at what age people, 
who born in a given period, will die on average, if the mortality rate in all age groups remains throughout their next life - from birth to complete extinction of their generation will remain the same as in this period. In this way it is possible to characterize all mortality rates for a given year or period, one generalized figure. The latter indicator is free from the influence of age differences and is suitable for comparing different oblasts for different periods.

Characteristics of life expectancy and average age of the population are an integral indicator of all structural characteristics of mortality, a statistical quintessence of the level of viability of the population. The negative process of natural reduction occurs against the background of the general loss of population and deformation of its age structure, the number of which is reduced in reproductive age - that is, the aging of the nation [9].

Ukrainians live 10 years less than residents of the countries of European Union (EU) and many countries of the Commonwealth of Independent States (CIS). In particular, Ukraine ranks are 150th among 223 countries in the world in terms of life expectancy. The average life expectancy in Ukraine is 69 years, in the EU-74 years, and in the CIS countries: in Georgia - 76.7, in Moldova 70.8, in Belarus -70.6, in Uzbekistan -71.9. Moreover, the average life expectancy of healthy living in Ukraine is 59.2 years, and in the European Union - 67 years. According to the State Statistics Committee, every tenth Ukrainian does not live to 35 years, and every fourth - to 60 years [4].

Authors consider the dynamics of changes in life expectancy in Ukraine, in the late 40's - first half of the 60 's in Ukraine there was significant progress in reducing mortality and increasing life expectancy in Ukraine. Thus, during the period 1950-1964 years, the average life expectancy at birth increased in men by 11.7 , and in women by 7.7 years (in men from 56.2 to 67.9, and in women from 66.8 to 74.5 years). According to the average life expectancy of the population of Ukraine in the first half of the 60's entered the top ten countries. Thus, in 1964 in Japan the average life expectancy was 67.2 years for men and 72.6 - for women, in the United States was 66.8 years for men and 73.6 - for women, in France - 68.0 years and 75.1 years, respectively [10].

More than two-thirds of the increase in life expectancy between 1950 and 1964 years was due to a reduction in infant and child mortality between the ages of 1 and 14. The highest growth rates of life expectancy occurred in 1950 - 1959 years, when their annual growth averaged 0.8 years for men and 0.5 years for women.

Positive changes in reducing mortality in Ukraine have been made possible by mass prevention and immunization of the population, the introduction of sulfamide drugs and antibiotics in the practice of health care, in particular their availability to the general public. A significant role also belongs to the purely demographic determinant - the huge losses of the adult population in the 30's and 40's from famine, repression and war [10].
Unfortunately, the reserves for reducing mortality, which were in effect until the mid-1960s, were largely exhausted, and over the next 20 years the mortality rate increased and life expectancy decreased. The main role in the deterioration of the mortality situation was played by the increase in the age probability of death in men from the age of 20 and in women from the age of 40 . As a result of these trends, life expectancy has decreased significantly. The minimum values of its indicators fall on 1980-1981 years (for men - 64.6 years, for women 74.0 years). During the period 1964-1981years, the average life expectancy of men decreased by 3.3 years, and that of women by 0.5 years (Table 3 ).

Table 3. Dynamics of life expectancy at birth of Ukraine (years) $[4,10]$

\begin{tabular}{|c|c|c|c|}
\hline \multirow{2}{*}{ Years } & \multirow{2}{*}{ Total } & \multicolumn{2}{|c|}{ Including } \\
\cline { 3 - 4 } & & men & women \\
\hline $1958-1959$ & 69.8 & 66.1 & 72.6 \\
\hline $1961-1962$ & 70.9 & 67.3 & 73.6 \\
\hline $1965-1966$ & 71.6 & 67.7 & 74.5 \\
\hline $1969-1970$ & 70.8 & 66.5 & 74.3 \\
\hline $1979-1980$ & 69.7 & 64.6 & 74.0 \\
\hline $1985-1986$ & 70.5 & 65.9 & 74.5 \\
\hline $1989-1990$ & 70.7 & 65.9 & 75.0 \\
\hline $1991-1992$ & 69.3 & 64.2 & 74.2 \\
\hline $1995-1996$ & 66.9 & 61.4 & 72.7 \\
\hline $1999-2000$ & 67.9 & 62.4 & 73.6 \\
\hline $2000-2001$ & 68.3 & 62.8 & 74.1 \\
\hline $2005-2006$ & 68.1 & 62.4 & 74.1 \\
\hline $2009-2010$ & 70.4 & 65.3 & 75.5 \\
\hline $2018-2019$ & 69.3 & 63.8 & 74.9 \\
\hline
\end{tabular}

Since the mid-1980's there has been a certain break in the unfavorable dynamics of mortality in Ukraine: the probability of mortality began to decline compared to the first half of the 1980's in almost all age groups, life expectancy increased in 1985-1987 by 1.7 for men and 0.9 years in women. After a twenty-year break, the average life expectancy of women in 1989 yr. exceeded the maximum values of this indicator by 0.5 years in the 1960s. However, it was not possible to consolidate the positive direction of the tendencies to reduce mortality. In the late 1980s and early 1990s, the negative trends in mortality that dominated the demographic sphere until 1985 are gradually recovering: there is an increase in the age probability of death in men and women from the age of 15. Life expectancy in 1992 compared to 1987 decreased by 3.0 years for men and 1.4 - for women.

For the entire period up to the mid-1990s, the average life expectancy of the urban population was on average 1.5-2.0 years higher than that of the rural population, and there is a tendency for them to equalize.

From 1990 to 2010 years there is a decrease in the overall life expectancy of the population of Ukraine by 0.3 years (from 70.7 to 70.4 years), for men - by 0.6 years (from 65.9 to 65.3 years) ), and women, on the contrary, increase - by 0.5 years (from 75.0 to 75.5 years). In 1989-1990 years., the life expectancy of women exceeded the life expectancy of men by 9.1 years, and in 2009-2010 years - by 10.2 years. In the period from 2010 to 2019 years, these changes amounted to 1.1 years. 
Of great concern is the significant reduction in life expectancy, which is the main criterion for the health of the population and the level of human development, as it is an integral embodiment of the processes of reproduction of both health and the population itself. The average value of this indicator today in Ukraine reaches 69.3 years and is the lowest among the countries of the European space. The worst performance on this parameter recorded in Zhytomyrska, Odeska, Mykolaivska, Dnipropetrovska, Chernihivska, Kirovohradska, Chernihivska oblasts (Table 4).

The best life expectancy indicators are observed in Ternopilska, Lvivska, Chernivteska, Ivano-Frankivska, Khmelnytska and Rivnenska oblasts. In other words, life expectancy is firmly held in the Western of the country, despite the fact that world practice shows longer life expectancy in economically developed oblasts (Fig. 1).

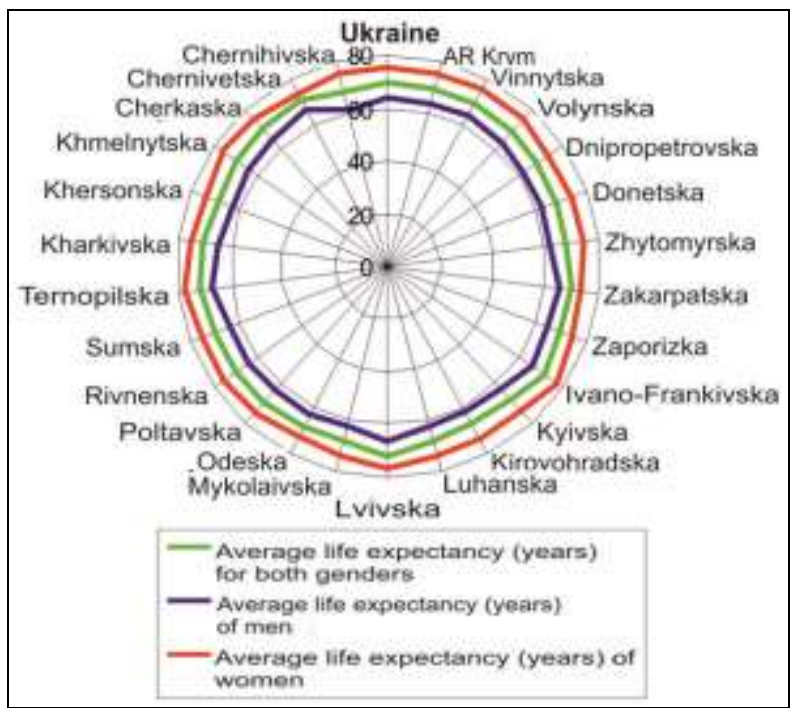

Fig.1. Territorial differentiation of life expectancy in 2019

The average life expectancy in Ukraine in 2018-2019 was 69.3 years, including 70.0 years in urban settlements and 67.8 years in rural ones.

In all oblasts of Ukraine, the average life expectancy of women significantly exceeds the same figure for men, and this difference is much greater than in economically developed countries (minimum - 6.8 years in Chernivetska oblast and maximum - 13.8 years in Chernihivska oblast) (Table. 4). Characteristically, $89 \%$

Table 4. Average life expectancy in the oblasts of Ukraine in 2019*

\begin{tabular}{|l|c|c|c|}
\hline \multirow{2}{*}{ Oblast** } & \multicolumn{2}{|c|}{$\begin{array}{c}\text { Average life } \\
\text { expectancy (years) }\end{array}$} & \multirow{2}{*}{$\begin{array}{c}\text { Difference of } \\
\text { years }\end{array}$} \\
\cline { 2 - 3 } & men & women & \\
\hline AR Krym & 63.7 & 74.8 & 11.1 \\
\hline Vinnytska & 64.9 & 75.8 & 10.9 \\
\hline Volynska & 63.7 & 75.8 & 12.1 \\
\hline Dnipropetrovska & 62.2 & 73.5 & 11.3 \\
\hline Donetska & 61.8 & 73.7 & 11.9 \\
\hline Zhytomyrska & 61.8 & 74.2 & 12.4 \\
\hline Zakarpatska & 64.8 & 73.7 & 8.9 \\
\hline Zaporizka & 64.2 & 75.0 & 10.8 \\
\hline Ivano-Frankivska & 66.4 & 77.0 & 10.6 \\
\hline
\end{tabular}

\begin{tabular}{|l|c|c|c|}
\hline Kyivska & 62.3 & 74.4 & 12.1 \\
\hline Kirovohradska & 61.9 & 73.8 & 11.9 \\
\hline Luhanska & 62.7 & 74.1 & 11.4 \\
\hline Lvivska & 66.3 & 77.0 & 10.7 \\
\hline Mykolaivska & 62.3 & 73.3 & 11.0 \\
\hline Odeska & 63.3 & 72.9 & 9.6 \\
\hline Poltavska & 63.8 & 74.9 & 11.1 \\
\hline Rivnenska & 64.0 & 75.6 & 11.6 \\
\hline Sumska & 63.5 & 75.0 & 11.5 \\
\hline Ternopilska & 66.6 & 77.4 & 10.8 \\
\hline Kharkivska & 64.9 & 75.2 & 10.3 \\
\hline Khersonska & 62.3 & 73.8 & 11.5 \\
\hline Khmelnytska & 64.4 & 75.9 & 11.5 \\
\hline Cherkaska & 64.4 & 75.4 & 11.0 \\
\hline Chernivetska & 66.9 & 73.7 & 6.8 \\
\hline Chernihivska & 61.3 & 75.1 & 13.8 \\
\hline
\end{tabular}

* Compiled by the authors according to the State Statistics Service of Ukraine $[4,10]$

** The names of the units of administrative division of Ukraine are represented in writing according to the [11]

of the oblast variation of this difference is explained by the male mortality regime, and the relationship is inverse - the higher the male mortality in the oblast, the smaller the gender difference in life expectancy at birth (Fig. 2).

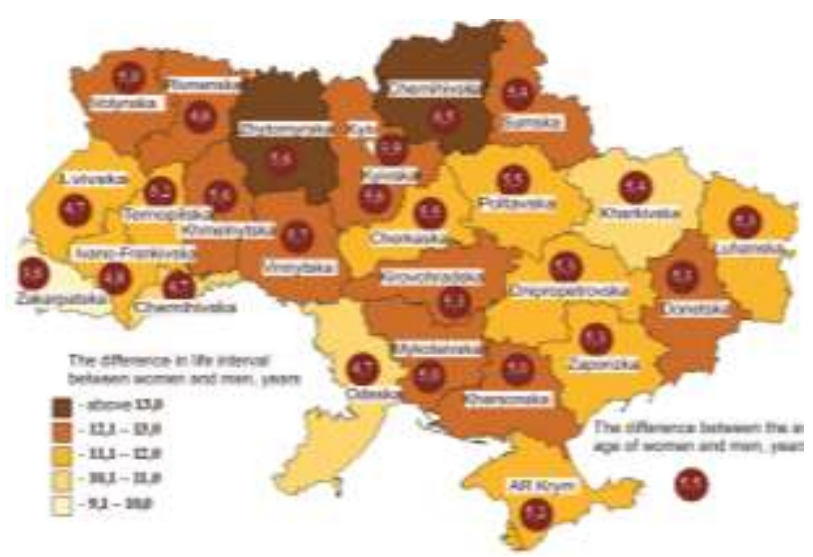

Fig. 2. Differences in life expectancy and average age of women and men in Ukraine*

* Compiled by the authors according to the State Statistics Service of Ukraine [4]

Differentiation of life expectancy at birth varies for women from 72.9 years in Odeska oblast to 77.4 years in Ternopilska oblast and for men from 61.3 year in Chernihivska oblast to 66.9 years in Chernivetska oblast.

In general, the life expectancy of the population of Ukraine is quite stable, for the male population it fluctuates from 62 to 64 years, for women the limits of variation vary from 73 to 76 years (Fig. 1). The life expectancy of the entire population of the country is approaching 70 years.

Life expectancy in urban settlements is 2.2 years higher than in rural ones (69.0 vs. 66.8). This is typical for all oblasts of Ukraine, except for the Zakarpatska oblast, where life expectancy in rural settlements is 0.9 years higher than in cities. The largest excess of life expectancy in urban settlements over rural ones was 
recorded in Chernihivska (5.5 years) and Zhytomyrska (4.4 years) oblasts.

The average life expectancy of men is 11.1 years less than that of women - 63.8 and 74.9, respectively (Fig. 2). This gap is larger in rural settlements (11.9 years) than in urban ones (10.6 years). The largest excess (13.8 years) is observed in the Chernihivsky oblast, and among the rural population it is 15.9 years. The smallest differences in the life expectancy of men and women are typical for Chernivetsky oblast - 6.8 years (for the general population) and 9.6 years - for the rural population [4].

The next indicator that significantly affects the gender and age structure of the population is the total fertility rate in the oblasts of Ukraine, as shown in Table 5 and Fig. 3 in 2019 by type of settlement had the following territorial differences.

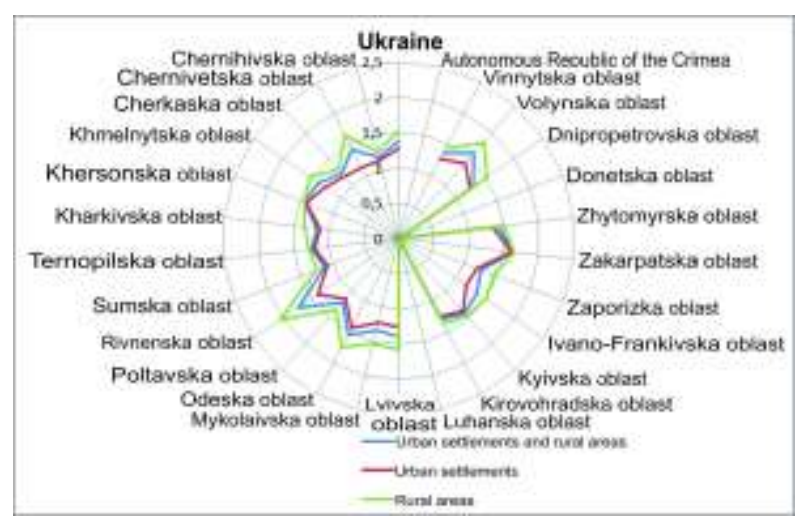

Fig. 3. Total fertility rate indicator in oblasts of Ukraine (2019)

With regard to rural areas, the group of oblasts with the highest total fertility rate in such oblasts as Odeska, Rivnenska and Volynska is distinguished in these oblasts, there is an almost simple type of reproduction. The second group of obalsts in which the total birth rate is close to a simple type of reproduction - Mykolaivska, Chernivetska, Dnipropetrovskf, Khmelnytskf, Zhytomyrska and Zakarpatska oblasts. Moderate indicators of the total birth rate in rural areas were observed in such oblasts as Zaporizhska, IvanoFrankivska, Chernihivska, Vinnytska, Kirovohradska, Lvivska, Khersonska, and Kyivska.

Table 5. Fertility rate indicator in Ukraine and oblasts (2019)*

\begin{tabular}{|l|c|c|c|}
\hline \multirow{2}{*}{ Oblasts** } & \multicolumn{3}{|c|}{$\begin{array}{c}\text { Total reproduction rate } \\
\text { (per 1 woman) }\end{array}$} \\
\cline { 2 - 4 } & $\begin{array}{c}\text { urban } \\
\text { and rural } \\
\text { settle- } \\
\text { ments }\end{array}$ & $\begin{array}{c}\text { urban } \\
\text { settle- } \\
\text { ments }\end{array}$ & $\begin{array}{c}\text { rural } \\
\text { settle } \\
\text { ment } \\
\text { s }\end{array}$ \\
\hline Ukraine & 1.374 & 1.283 & 1.522 \\
\hline AR Krym & - & - & - \\
\hline Vinnytska & 1.355 & 1.268 & 1.438 \\
\hline Volynska & 1.617 & 1.421 & 1.82 \\
\hline Dnipropetrovska & 1.287 & 1.236 & 1.527 \\
\hline Donetska & - & - & - \\
\hline Zhytomyrska & 1.415 & 1.345 & 1.503 \\
\hline Zakarpatska & 1.641 & 1.617 & 1.649 \\
\hline Zaporizka & 1.25 & 1.185 & 1.448 \\
\hline
\end{tabular}

\begin{tabular}{|l|c|c|c|}
\hline Ivano-Frankivska & 1.358 & 1.164 & 1.507 \\
\hline Kyivska & 1.412 & 1.38 & 1.457 \\
\hline Kirovohradska & 1.301 & 1.247 & 1.366 \\
\hline Luhanska & - & - & - \\
\hline Lvivska & 1.392 & 1.263 & 1.576 \\
\hline Mykolaivska & 1.337 & 1.228 & 1.533 \\
\hline Odeska & 1.543 & 1.429 & 1.739 \\
\hline Poltavska & 1.213 & 1.132 & 1.342 \\
\hline Rivnenska & 1.735 & 1.4 & 2.049 \\
\hline Sumska & 1.13 & 1.079 & 1.239 \\
\hline Ternopilska & 1.253 & 1.205 & 1.279 \\
\hline Kharkivska & 1.168 & 1.126 & 1.348 \\
\hline Khersonska & 1.432 & 1.407 & 1.435 \\
\hline Khmelnytska & 1.385 & 1.273 & 1.53 \\
\hline Cherkaska & 1.231 & 1.171 & 1.297 \\
\hline Chernivetska & 1.426 & 1.136 & 1.653 \\
\hline Chernihivska & 1.181 & 1.138 & 1.262 \\
\hline
\end{tabular}

* Compiled by the authors according to the State Statistics Service of Ukraine [4, 10]

** The names of the units of administrative division of Ukraine are represented in writing according to the [11]

The lowest indicators of the total birth rate in rural areas were observed in Poltavskaa, Sumska, Chernihivska, Cherkaska, Ternopilska oblasts.

The situation is somewhat different with regard to the distribution of oblasts according to the total fertility rate for urban areas:

- the highest indicators are typical for the Volynska and Zakarpatska oblasts;

- moderate indicators of the total birth rate in urban areas were observed in such oblasts as Odeskaa, Khmelnytska, Vinnytska, Kirovohradska, Lvivska, Khersonska, Ternopilska;

- the lowest indicators of the total birth rate in urban areas were observed in Ivano-Frankivska, Chernihivska, Chernivetska, Cherkaska oblasts.

In 2019, the lowest indicators of this rate were 1.11.2 , that is, they were already approaching that limit beyond which there is no simple reproduction of the population.

It should be noted that the birth rate remains low, as it compensates only $59 \%$ of the reproduction of the population of Ukraine [4].

Based on the study of indicators influencing the formation of gender and age structure of the population of Ukraine, analysis of demographic factors, taking into account the current demographic situation, we came to a number of conclusions.

\section{Conclusions}

Gender - age structure of the population is one of the important demographic indicators, which characterizes the demographic situation. Characteristics of the age structure of the population and the ratio of men and women (in general and by individual age groups) are needed for the calculation and evaluation of labor resources, the contingent of preschool and school age children, retirees, as well as to plan the range of 
consumer goods. The gender structure of the population of Ukraine of 2019 is dominated by women; the share of women is $53.9 \%$, and men $-46.1 \%$ [4]. The relationship between men and women in different age groups is different. The modern social norm of balancing is considered to be the age of 50 years. The age of balancing between the male and female population of Ukraine according to 2019 data is 30 years. The huge shortage of older men was affected by the losses in the war of 1941-1945. The change in the ratio of gender groups and its imbalance was also influenced by the different intensity of migration of men and women. High mortality among the male population, especially those of working age, has too great an impact on the gender imbalance. Therefore, reducing male mortality is one of the main tasks of socio-demographic development, which should be addressed at the national level.

The age structure of the population of Ukraine has a clear tendency to aging. The identified negative trends in the formation of gender and age structure of the population of Ukraine (increase in the share of elderly people, decrease in demographic potential) put forward urgent tasks to overcome the demographic crisis, which is possible only with a significant increase in living standards, targeted influence on social transformation, infrastructure, ensuring uniform living standards in all oblasts of the country, in urban and rural areas. This will provide basic social guarantees for the vast majority of the population and reduce the quantitative and qualitative losses of society from the demographic crisis.

\section{References}

1. V.O. Dzhaman, V.P. Krul, H.Ya. Cherniukh Demoheohrafiia: Navchalnyi posibnyk (Demogeography: Textbook). (Ruta, Chernivtsi, 2002)

2. Ptoukha Institute for Demography and Social Studies of the National Academy of Sciences of Ukraine (2021), https://www.idss.org.ua. Accessed 22 Jan 2021
3. O.H. Topchiiev, V.V. Yavorska, N.V. Dimova Heodemohrafiia: rehionalnyi demohrafichnyi rozvytok Ukrainy (Geodemography: regional demographic development of Ukraine). (BMB, Odesa, 2014)

4. Official site of the State Statistics Committee of Ukraine (2021), http://www.ukrstat.gov.ua. Accessed 20 Jan 2021

5. E.M. Libanova, O.V. Makarova, O.V. Pozniak, P.Ye. Shevchuk, V.S. Shyshkin Zainiatist ta rynok pratsi (Employment and labor market). (NASU, Kyiv, 1999)

6. T.S. Morshchenok (2009), Demohrafichni peredumovy formuvannia trudovoho potentsialu (Demographic prerequisites for the formation of labor potential)

http://dspace.nbuv.gov.ua/bitstream/handle/1234567 89/2856/st_44_29.pdf. Accessed 27 Jan 2021

7. I.V. Ponomarenko, Study of the impact of population aging on the number and structure of economically active population in Ukraine and European countries. Efficient economy, 1 (2013)

8. V.S. Steshenko, V.P. Piskunov, Demographic knowledge: current status and development prospects. Demography and social economy, 1 (2012)

9. E.M. Libanova, S.I. Pyrozhkov, N.S.Vlasenko Demohrafichna kryza v Ukraini: yii prychyny ta naslidky: Monohrafiia (Demographic crisis in Ukraine: its causes and consequences: Monograph). (Kyiv, 2003)

10. V.V. Yavorska Rehionalni heodemohrafichni protsesy v Ukraini (Regional geodemographic processes in Ukraine). (Aksioma, KamianetsPodilskyi, 2013)

11. Toponymic guidelines for map and other editors, for international use: Ukraine (State Service of Geodesy, Cartography and Cadastre, Kartographia, Kyiv, 2 